Article

\title{
New Alliances in Post-Brexit Europe: Does the New Hanseatic League Revive Nordic Political Cooperation?
}

\author{
Daniel F. Schulz * and Thomas Henökl \\ Department of Political Science and Management, University of Agder, 4630 Kristiansand, Norway; \\ E-Mails: daniel.schulz@uia.no (D.F.S.), thomas.henokl@uia.no (T.H.) \\ * Corresponding author
}

Submitted: 15 June 2020 | Accepted: 17 July 2020 | Published: 3 November 2020

\begin{abstract}
As Brexit removes the Nordic countries' most powerful ally from the EU, what does this imply for their approach to European affairs? The literature on small states within the EU suggests that they can counterbalance limited bargaining capacities by entering two types of alliances: strategic partnerships with bigger member states and institutionalised cooperation on a regional basis. Against this backdrop we ask whether, by significantly raising the costs of non-cooperation for Nordic governments, the Brexit referendum has triggered a revival of Nordic political cooperation. We scrutinise this conjecture by analysing Nordic strategies of coalition-building on EU financial and budgetary policy, specifically looking at attempts to reform Europe's Economic and Monetary Union and proposals to strengthen the EU's fiscal powers. We find that Nordic governments have successfully collaborated on these issues in the context of new alliances such as the 'New Hanseatic League' or the 'Frugal Four.' Yet, their coalition-building strategies rely on relatively loose and issue-specific alliances rather than an institutionalisation of Nordic political cooperation, implying that this revival of Nordic political cooperation hardly involves the institutions of 'official' Nordic cooperation. We argue that this reflects lasting differences among the Nordics' approach to the EU as well as electorates' scepticism about supranational institution-building, implying that 'reluctant Europeans' are often also 'reluctant Scandinavians.'
\end{abstract}

\section{Keywords}

Brexit; budgetary politics; Economic and Monetary Union; fiscal integration; intergovernmentalism; Nordic cooperation; small states

Issue

This article is part of the issue "Rediscovering Nordic Cooperation" edited by Anne Elizabeth Stie (University of Agder, Norway) and Jarle Trondal (University of Agder, Norway/ARENA University of Oslo, Norway).

(C) 2020 by the authors; licensee Cogitatio (Lisbon, Portugal). This article is licensed under a Creative Commons Attribution 4.0 International License (CC BY).

\section{Introduction}

The Brexit referendum of 2016 has led to much soulsearching about the future of European integration. While its outcome sent shockwaves across Europe, its impact was felt more in some places than in others, with the Nordic countries being among the hardest hit. Not only did a British exit imply the loss of the Nordics' most powerful ally in European negotiations, which often led a 'market-making coalition' focused on market liberalisation and free trade (Quaglia, 2010). It also brought about the prospect of a power shift in Brussels favouring euro area countries, potentially pushing the euro outsiders among the Nordics further to the side lines (Huhe, Naurin, \& Thomson, 2020). Hence, the events since 2016 have forced Scandinavian governments to rethink their approach toward European integration.

The literature on 'small states' typically assumes that all Nordic countries confront similar structural disadvantages in EU policymaking due to their relatively limited bargaining power and constrained financial resources. However, research in this tradition has also shown that 
small states can and do successfully influence EU policy and that coalition-building is decisive for success (Thorhallsson \& Wivel, 2006). Similarly, Diana Panke argues that small states' limited bargaining power "can potentially be counterbalanced with two strategies: institutionalised coordination on a regional basis and strategic partnerships with bigger states" (Panke, 2010, p. 802). While the latter strategy implies forging strong ties with one of the EU's 'great powers' in an asymmetric relationship, the former relies on a pooling of powers among equals.

This juxtaposition between two complementary strategies serves as the starting point for our analysis. We investigate how the Nordic countries seek to compensate for the loss of its most important 'big power' ally within the EU after 2016. Do they focus on strategic partnerships, replacing one big partner with another, or do they instead try to further institutionalise Nordic cooperation to defend their joint interests in EU negotiations? Given that the Nordic countries have long been recognised for being particularly effective in turning intraNordic cooperation into extra-Nordic influence (Grøn \& Wivel, 2018), this article asks if Brexit has brought about a revival of Nordic political cooperation.

Our analysis focuses on the area of EU financial and budgetary policy with a special emphasis on reforming Economic and Monetary Union (EMU) and discussions about strengthening the EU's fiscal powers. We focus on these reforms as 'crucial cases' for two reasons: First, recent reform initiatives in this area all seek to further strengthen the euro through the creation of additional supranational institutions and are thus emblematic of integration schemes observed with scepticism by both the Nordics and its now-lost ally. As these initiatives carry the potential to irreversibly alter the path of European integration in a more federalist direction, the stakes for the Nordics are high and we should expect them to adopt a public position. At the same time, however, EMU reform poses a 'tough test' for Nordic cooperation since only one of the five Nordic countries, Finland, is an EMU member state, which may make coordination among the Nordics particularly challenging. Hence, EMU reform may serve as a least likely case for effective Nordic coordination on EU policy. This implies, to invoke Jack Levy's 'Sinatra inference,' that if the Nordics can make it here, they can make it anywhere (Levy, 2002).

While detailed negotiations are still ongoing, the empirical record thus far suggests that the Nordics have indeed increased their collaborations to fight off ambitious reform proposals. They have successfully stunted ambitions to create a genuine euro area budget with a stabilisation function or to increase the size of the long-term EU budget. While they made concessions on the Covid-19 recovery fund, they received substantial increases to their budget rebates in return. Yet, these results were mostly achieved through cooperation within loosely defined alliances such as the 'New Hanseatic League' or the 'Frugal Four' which also involved other countries such as the Baltic states, Ireland, Austria, or the Netherlands. These ad-hoc coalitionbuilding attempts were driven by intergovernmental cooperation rather than by strengthening the role of the official institutions of 'Norden' - that is: the Nordic Council and the Nordic Council of Ministers-in EU affairs. Furthermore, actual attempts to further institutionalise official Nordic cooperation on EU policy have been blunted, as the resistance to creating a common representation in Brussels shows.

We argue that this mixed record of Nordic political coordination after Brexit reflects the very same mechanisms that have made the Nordic countries 'awkward partners' in European integration in the first place. First, Nordic political elites and electorates share a deepseated scepticism towards supranational arrangements which limit national autonomy (Stegmann McCallion \& Brianson, 2018, p. 6), be they European or Nordic. Due to this hesitation regarding pooling resources in a lasting fashion, Nordic countries favour flexible and issue-specific alliances over a long-term institutionalisation of Nordic cooperation in EU affairs, which may involve strengthening supranational institutions at the regional level.

Second, despite often being viewed as a relatively coherent bloc, there is great variation between the five Nordic states' and their preferences on EU policy. The experience of the sovereign debt crisis in the euro area and the Brexit vote may have brought Finland-the EU's former poster child of the North-closer to its more sceptical neighbours. Yet, the simple fact that Nordic cooperation brings together non-EU members (Norway and Iceland) and EU members with formal (Denmark) and de facto (Sweden) opt-outs, already reveals the difficulties associated with making institutionalised Nordic cooperation a central tool for ensuring national interests, since these may not always be well-aligned. This matters because utilising institutionalised cooperation to counterbalance limited bargaining power presupposes homogeneous interests within groups (Panke, 2010, p. 803), which cannot be taken for granted in the case of Nordic cooperation.

The remainder of this article is structured as follows: The next section situates Nordic strategies toward EU policy in the wider literature on 'small states' in European integration, discussing the strategic options smaller member states have at their disposal to influence policy in general and how the Nordic countries make use of them in particular. It also discusses the relationship between Nordic cooperation and European integration in this light. The following section illustrates these dynamics empirically by analysing Nordic approaches towards EU financial and budgetary policies after Brexit, focusing on the coalitional logics the Nordics have utilised to influence reform outcomes. We conclude by highlighting the implications of our analysis for the future of European integration and Nordic cooperation. 


\section{Small States in European Integration: What Strategies for the Nordic Countries?}

While all European countries are small by global standards, what constitutes a small state in the context of European integration is far from obvious. Hence, researchers frequently use proxies such as population size, voting weights, or GDP to distinguish small states from middle powers and big players. Despite this lack of a commonly agreed definition, however, there is little doubt that the EU enlargements of 1995 and 2004 have drastically changed the balance between smaller and bigger member states. If we follow Panke and Gurol (2019) in identifying countries as 'small' if their populations are smaller than the EU27 average of 16,5 million, then 20 out of 27 member states fit that definition, including all Nordic countries.

Even if Europe's small states already displayed a surprising 'strength of the weak' when adjusting to the rapid changes in the global economy throughout the 1970s and 1980s (Katzenstein, 1985), the prospect of economic integration offered additional advantages. As members of a large single market, for instance, small states could reap benefits associated with large economies such as economies of scale and increased competition. However, this came at the cost of potentially playing only a minor role in collective decision-making processes. As Thorhallsson and Wivel (2006, p. 658) aptly summarise, such steps in integration make small states "at the same time more dependent on strong international institutions and less able to influence their decision-making."

\subsection{Structural Disadvantages in EU Decision-Making}

Small states confront several obstacles in their attempts to influence decision-making at the EU level, with limited voting power being only the most obvious impediments. Outside of intergovernmental conferences, the increasing use of qualified majority voting in EU decisionmaking is theorised to weaken small state influence on EU decision-making further. Given that the informal norms of decision-making by consensus rather than formal voting remains the primary mode of decision-making (Heisenberg, 2005), the impact of qualified majority voting on small-state influence should not be overstated. Even within a consensus culture, however, small states face size-related disadvantages. As they tend to have smaller public budgets, their ministries and embassies usually manage the same workload with significantly fewer staff. In the context of EU negotiations, such capacity constraints may result in delayed or vague positions, decreasing the argumentative power required for negotiation strategies focused on persuasion (Panke, 2010).

The small states literature has identified a list of counterstrategies that small states may employ to overcome such disadvantages. First, the 'rotating Council Presidency' offers smaller states a platform to promote niche national interests or novel policy ideas (Bengtsson,
Elgström, \& Tallberg, 2004). Holding the Presidency offers an important window of opportunity to increase 'soft' or normative power for countries lacking hardpower resources. Second, somewhat paradoxically, the relative weakness of small states allows them to adopt a role as 'honest brokers.' As they cannot expect to successfully push through their national interests in the same way as countries like France or Germany do, small states are less likely to meet the same level of suspicion when tabling a compromise. A reputation as honest brokers then also allows small states to shape the agenda as 'norm advocates' (Björkdahl, 2008) or policy 'frontrunners and role models' (Jakobsen, 2009). Third, selective engagement and prioritisation allows small states to concentrate their limited resources on those issues where they have the most important economic and political interests at stake. If small states adopt positions only relatively infrequently, this means that "when they do, decision-makers in the Council are particularly attentive to them" (Arregui \& Thomson, 2009, p. 660).

While the above counterstrategies apply to small member states individually, the literature suggests that for small states to successfully influence EU policy, "coalitionbuilding has been decisive" (Thorhallsson \& Wivel, 2006, p. 660). Here, Panke (2010) usefully distinguishes two complementary approaches to coalition-building: strategic partnerships with bigger states such as France, Germany, or (formerly) the UK on the one hand, and institutionalised coordination on a regional basis on the other. While the former implies an asymmetric partnership, the latter approach suggests a more balanced power relationship within an alliance that cannot be divided into 'leaders' and 'followers' as clearly. Typical examples of such regional-based horizontal alliances include the Benelux, Nordic cooperation, the Baltic group, or the Visegrad Four. The analysis below seeks to shed light on the open question of whether strategic partnerships and horizontal coordination can be substitutes and, more specifically, whether Brexit increases the utilisation of horizontal cooperation among the UK's Northern allies.

\subsection{The Nordic Approach as a Success Case of Small State Influence?}

While voting procedures and capacity constraints could lead us to expect that small states hold both less bargaining power and argumentative power than bigger EU members, the empirical record remains inconclusive. An empirical analysis of national bargaining success on EU legislation, for instance, finds France and Germany doing poorly and small states like Ireland, Luxembourg, or the Nordic states doing 'particularly well' (Golub, 2012, p. 1311). Similarly, studies of the intergovernmental conferences (IGCs) at Amsterdam and Nice did not find that large member states hold outsize bargaining power (Finke, 2009; Slapin, 2008). Hence, it is not a foregone conclusion that small states are powerless, neither in 'ordinary' legislative decision-making nor at extraordinary IGCs. 
Among the heterogeneous group of small member states, the Nordics are typically seen as particularly active and effective in enshrining their preferences in EU legislation (Panke, 2010, 2011). Their success is somewhat surprising, given that the Nordics are relative latecomers and often regarded as 'reluctant Europeans' (Grøn, Nedergaard, \& Wivel, 2015; Miljan, 1977). If we assume that experience with EU decision-making implies learning and comes with extensive knowledge and networks, these resources should be less pronounced for relatively new member states like Sweden and Finland, which only joined in 1995. One might therefore expect the Nordics to carry less influence in Brussels than more seasoned groupings such as the Benelux countries (Maes $\&$ Verdun, 2005). However, Daniel Naurin (2007) provides evidence that the Nordic countries have quickly developed large amounts of network capital to cooperate at the EU level, with Sweden lagging behind only the 'big three' and being far better connected than larger member states such as Spain or Italy.

Alongside network capital and a strategy of prioritisation and selective engagement, normative power has been another key source of Nordic influence. Sweden and Denmark in particular are proud promoters of the 'Nordic model' of welfare and labour market policy and their attempts to export the model has been quite successful within the EU (Bengtsson et al., 2004). A striking example may be seen in the adoption of 'flexicurity' as a core element of the European Commission's reform recommendations to many EU member states in the context of the European Semester process (Bekker, 2018; Haas, D'Erman, Schulz, \& Verdun, 2020). Other prominent examples include Finland's 'Northern Dimension Initiative' (Arter, 2000) and Denmark's success in coordinating the Eastern enlargement process during its 2002 presidency (Bengtsson et al., 2004).

A pertinent question in the current period of change, however, is to what extent Brexit will negatively affect the hitherto effective strategies of the Nordics. Given that Denmark and Sweden have the closest network ties to the UK and have traditionally held the most similar policy positions, they face particularly high hurdles in maintaining previous levels of influence. Thus, both countries are among those most "likely to become significantly less central in Council networks if they do not take compensating measures" (Huhe et al., 2020, p. 154). It remains an open question whether such compensating measures focus on building new strategic partnerships (e.g., by collaborating more closely with Germany) or emphasise horizontal coordination instead by turning intra-Nordic cooperation into a platform for extra-Nordic influence to a greater extent than in the past.

\subsection{Nordic Cooperation and European Integration: A Difficult Relationship}

The history of Nordic political cooperation has been characterised as "littered with grand schemes that never materialized" (Grøn \& Wivel, 2018, p. 272). Despite setbacks, however, the project has continuously moved on. As one striking example, the creation of the Nordic Council of Ministers followed failed discussions to establish a Nordic common market as an alternative to the European Economic Community. This example already underlines that Nordic cooperation has always been influenced by the broader European integration project. It is thus no coincidence that the future of 'Norden' is back on the agenda at a time when the EU itself appears to be at a crossroads (Olesen \& Strang, 2016).

In the context of EU affairs, it is useful to distinguish informal formats from 'official' cooperation in the context of the Norden institutions, the Nordic Council and the Nordic Council of Ministers. While informal interaction formats such as breakfast meetings of Nordic ministers prior to EU summits are well established and serve a useful purpose in pooling information and expertise (Ruse, 2015, pp. 54-56), the role of the Nordic Council and the Nordic Council of Ministers in coordinating Nordic EU policy remains significantly less clear, not least because these institutions include both EU insiders (with varying numbers of opt-outs) and outsiders. Following the contrasting outcomes of several referendums on EU membership in the fall of 1994, Norway and Iceland stayed on the outside, while Sweden and Finland joined Denmark as EU members-with direct consequences for Nordic cooperation (Gänzle \& Henökl, 2018). The Nordic Council responded to this challenge by radically overhauling its internal structures. Instead of following policy areas as organising principle, three pillars were adopted including EU relations and cooperation with neighbouring regions (especially the Baltics) alongside intra-Nordic matters (Opitz \& Etzold, 2018). While the three-pillar structure proved unworkable and was hence abandoned after only five years, many attempts to strengthen the coordination of EU policy within 'official' Nordic cooperation followed.

The latest reform program, Nyt Norden (The New North), emphasises the need to make official Nordic cooperation more political and relevant, especially for international and European affairs (NORDEN, 2016a). The aim appears to be to counter the increased marginalisation of the Nordic Council and the Nordic Council of Ministers since the 1990s, when a strengthened role of the prime ministers translated into governments' preferences for cooperating 'informally and outside the old institutions' (Olesen \& Strang, 2016, p. 35). While the Nordic Council of Ministers has increasingly focused on the EU in recent years, it may still be better understood as a forum for discussions rather than coalition-building of a Nordic 'bloc.' Hence, Grøn and Wivel (2018, p. 276) describe the role of 'official' Nordic cooperation within EU affairs as an arena for sharing information and informally testing arguments rather than finding common policy positions and strategies. Our modest ambition for the empirical discussion below is to assess to what extent Brexit may have changed this pattern by also giving the 
institutions of 'official' Nordic cooperation a bigger role in EU policy.

\section{Nordic Cooperation on EU Financial and Budgetary Policies After Brexit}

Our analysis focuses on the area of EU financial and budgetary policy, which offers a particularly 'tough test' for Nordic influence. This includes initiatives to reform the EMU and to increase the EU's budgetary powers. The Nordic countries' highly differentiated patchwork of integration arrangements in this area are likely to make intraNordic coordination on these issues particularly challenging. However, these developments also constitute crucial cases for the Nordics because recent EMU reforms involve a significant deepening of European integration in the area of core state powers and thus threaten to further decouple the Nordic countries from 'core Europe.' What is more, ambitious proposals to create supranational institutions are emblematic of centralising ambitions always observed with scepticism by the Nordics. Attempts to bolster the EU's and the euro area's fiscal powers also go directly against Sweden's and Denmark's traditional strategy to selectively and defensively engage with European integration in order to preserve crucial 'bastions of national autonomy' (Wivel, 2018, p. 14).

\subsection{The New Hanseatic League and EMU Reform}

On the pertinent issue of EMU reform, the Nordic countries have responded to the Brexit shock by joining the so-called 'New Hanseatic League' as the perhaps most visible new grouping in EU politics. Bringing together small states with a strong preference for free trade and balanced books, the alliance emerged at the end of 2017 and built on the long-standing practice of organising informal meetings among the Nordic and Baltic EU members (NB6) prior to Council meetings in Brussels (Schoeller, 2020). In addition to the Nordic and Baltic states, Ireland and the Netherlands joined the new coalition. Notably, this implies that Denmark and Sweden were the only euro outsiders within the group, giving them the opportunity to retain a voice in debates about the future of the euro. The group's most tangible output consisted in a series of position papers published throughout 2018, focused on Banking Union, Capital Markets Union, and the reform of the European Stability Mechanism, respectively. Taken together, these reforms constitute a potentially farreaching deepening of European integration without renegotiating the treaties.

From a Nordic perspective, these initiatives (and the Banking Union in particular) constitute a critical fork-inthe-road. While Finland joined the Banking Union by virtue of its EMU membership, Sweden and Denmark have set up national taskforces to address the question of whether to join on a voluntary basis through an arrangement called 'close cooperation.' Both have ini- tially decided not to opt in based on concerns about paying for bank failures in other member states and a preference of regulatory autonomy (Spendzharova \& Bayram, 2016). However, unlike the UK, both have not vocally opposed the Banking Union and, after the publication of reports by government commissions at the end of 2019 (Danish Ministry of Industry, Business and Financial Affairs, 2019; Swedish Ministry of Finance, 2019), Denmark and Sweden are currently further exploring the option of joining. Their final position will likely be of critical importance for their future approach to European integration. As the Banking Union requires the funding of a common safety net for dealing with the resolution of struggling banks, sceptics see it as a steppingstone in the direction of fiscal union. Staying on the outside thus threatens to open an even wider gulf between euro insiders and outsiders-an unfortunate development from the perspective of the Nordics (Brianson \& Stegmann McCallion, 2020; Korkman, 2015).

With a future opt-in to the Banking Union still in the cards for the Nordic euro outsiders, negotiations about completing the Banking Union were of relevance for them as well. When the New Hanseatic League first issued a position in 2018, new institutions for banking supervision and resolution had already been created, focussing the Banking Union debate squarely on the missing third pillar, a European Deposit Insurance Scheme, to replace existing national or regional schemes (Howarth \& Quaglia, 2018). While the New Hanseatic League did not generally rule out the creation of a common backstop for banking crises or a European Deposit Insurance Scheme, it made any discussions on completing the Banking Union conditional on prior efforts to reduce legacy debts at the national level (Hanseatic League, 2008a). This discussion specifically centred on the amount of nonperforming loans on Southern European banks' balance sheets as a legacy of the sovereign debt crisis. The New Hanseatic League demanded far-reaching national efforts in risk-reduction as a precondition for any sort of risk-sharing.

Similar as with their published positions on the Capital Markets Union (Hanseatic League, 2008b) and the European Stability Mechanism reform (Hanseatic League, 2008c), the New Hanseatic League remained closely aligned with German preferences. The group has consistently positioned itself as fiscal hawks opposing any form of redistribution within the euro area or grand leaps in European integration-reportedly with the 'tacit approval from Berlin' (Khan, 2018). Hence, the Nordics' strategy under the umbrella of the New Hanseatic League combines both elements of coalitionbuilding: coordination with like-minded small states while also seeking German support. This has led the Financial Times to conclude that the success of the New Hanseatic League's attempts to replace Britain will "be determined by their ability to persuade the bigger EU states, and particularly Germany, to join them" ("A daunting task," 2018). 


\subsection{The 'Frugal Four' and Opposition to Centralising Fiscal Powers}

Yet another informal format took centre stage in debates about the EU's budgetary powers. Denmark and Sweden joined Austria and the Netherlands under the label of the 'Frugal Four,' to position themselves jointly as advocates of budgetary discipline from 2018 onwards. The policy initiatives of the group can be seen in three interventions designed to prevent fiscal transfers and a further delegation of budgetary powers to Brussels: opposition to a budgetary instrument for the euro area, to an EU budget bigger than 1 percent of EU GDP, and to issuing joint debt to fund the recovery from the Covid-19 crisis. While the Frugal Four succeeded on the first two counts, their opposition did not prevent a deal on the EU's recovery fund.

The idea to create a euro area budgetdubbed Budgetary Instrument for Convergence and Competitiveness-forms part of French president Emmanuel Macron's broader vision for European integration expressed in his Sorbonne speech in 2017. When Germany endorsed a watered-down version of the idea as part of the 'Meseburg Declaration' of June 2018, this change of position invoked the fear among the Frugal Four that Germany might make too many concessions to France and hence triggered their open and proactive opposition (Schoeller, 2020). While the instrument originally was meant to be large enough to provide the euro area with enough fiscal firepower to fight economic downturns, the Frugal Four under the leadership of Dutch prime minister Mark Rutte successfully reined in Macron's ambitions through public interventions (Verdun, 2020). After lengthy discussions, an agreement on the Budgetary Instrument for Convergence and Competitiveness's design in October 2019 saw its scope and scale shrunk dramatically: It was thought to receive only $€ 17$ billion of basic funding for the period of 2021-2027 and hence did not allow for fiscal transfers to counteract asymmetric shocks. When the Covid-19 crisis spurred proposals for a much bigger (but temporary) recovery fund in May 2020, the small (but permanent) Budgetary Instrument for Convergence and Competitiveness was "unceremoniously scrapped" (Brunsden \& Fleming, 2020) altogether.

In parallel discussions about the EU's long-term budget for 2021-2027 (the multiannual financial framework), the Frugal Four drew the line at 1 percent of EU GDP. They predictably opposed the Commission's plans to preserve the EU's spending power despite the loss of the UK's contributions because they, as net contributors, would potentially face substantially higher costs. In a joint opinion piece issued in February 2020, the 'frugal' heads of government reiterated their 1 percent limit and demanded "a system of permanent corrections to protect individual states from having to shoulder excessive budgetary burdens" (Kurz, 2020). Again, the planned negotiations of the multiannual financial frame- work were derailed by the beginning of the Covid-19 crisis, leading to a completely new stage and intensity of budgetary negotiations.

As the economic fallout of the Covid-19 lockdowns became clearer in the following months, fiscal policy debates focused on how to fund the recovery. Mirroring earlier discussions about 'eurobonds,' an initiative led by France, Spain, and Italy to issue joint European debt (christened 'coronabonds') was opposed by the Frugal Four and Germany and hence quickly stalled in April 2020. Yet in a dramatic turn of events, German chancellor Merkel and French President Macron issued a joint proposal on May 18 to jointly fund $€ 500$ billion worth of grants to countries hit hardest by the pandemic. Remarkably, this proposal did not only include sizable (non-repayable) fiscal transfers, but also foresaw the European Commission issuing debt and thus setting a precedent for large-scale, centralised borrowing in the EU. Within a week, the Frugal Four issued a counterproposal focused on (repayable) loans worth $€ 250$ billion. Their proposal emphasised the 'temporary, one-off nature' of the fund and argued for strict economic conditionality and against any mutualisation of debt (Frugal Four, 2020). The European Commission followed on May 27 by issuing its own proposal for a $€ 750$ billion recovery fund (dubbed 'Next Generation EU'), which combined grants worth $€ 500$ billion with loans of $€ 250$ billion.

Frugal opposition determined the headlines in the run-up to a crucial EU summit to negotiate both the multiannual financial framework and the recovery fund, when numerous European leaders visited the Dutch PM as the informal spokesperson of the frugal group to persuade them (Khan \& Brunsden, 2020). Throughout the tense negotiations at what would become the secondlongest summit meeting in the EU Council's history (July 17-21, 2020), the key battle lines focused on the ratio between grants and loans and governance issues, with the Frugal Four insisting on retaining national vetoes over the disbursements of money to other member states. The deadlock was ultimately broken when the 27 heads of state and government agreed on a $€ 1,074$ billion longterm budget plus a $€ 750$ billion Covid-19 recovery fund. While the Frugal Four dropped their opposition to the disbursement of any non-repayable grants, they succeeded in reducing their value from $€ 500$ billion to $€ 390$ billion. Similarly, the agreement does not foresee national vetoes but a temporary 'emergency brake' (of up to three months) if individual member states feel that other member states do not fulfil the reform promises made in return for the funds received. As the joint negotiation of the long-term budget and the recovery fund gave ample room for horse trading, the Frugal Four received substantially increased rebates for their budget contributions in return for their agreement. Hence, they ultimately signed on to a deal widely perceived as a historic leap forward in European integration.

While the budget rebates and reduced volume of grants allowed the Frugal Four to present the deal as a 
success to their domestic constituencies, it may prove to be a pyrrhic victory in the long run. The summit negotiations clearly saw small states punching well above their weight; yet the final agreement establishes the principle of joint EU borrowing and thus marks a decisive step towards fiscal integration. To repay some of the borrowed sums, EU-wide plastic taxes or carbon border fees are currently being discussed, which suggest that Europe has "boarded the train towards more common taxation and cannot get off and turn back" (Sandbu, 2020). Despite their powerful resistance at the July 2020 summit, its final outcome therefore contradicts the Nordics' preferences for limited integration in important ways. Why?

Compared to the case of EMU reform, two elements reduced the Nordics' bargaining position on EU budgetary politics. First, they found themselves opposed by Germany on several counts. Their position to reduce the overall size of the multiannual financial framework took a hit when Germany signalled its willingness to increase its own budgetary contributions early on. More dramatically, the Frugal Four counterproposal for a Covid-19 recovery fund did not only draw the ire of its usual opponents in the South but German misgivings, too. This suggests that Nordic cooperation on EU affairs after Brexit may require tacit German approval to be effective. Second, the Nordic countries failed to present a united front after Finland broke the ranks. Following parliamentary elections in 2019, the new centre-left government changed course by clarifying that "Finland's policy on Europe does not involve a single-handed commitment to Hanseatic Leagues or any other blocs; instead, we collaborate with everyone and foster the unity of the EU" (Finnish Government, 2019). While Finnish positions on budgetary matters were often not substantially different from those of the Frugal Four, domestic politics produced a change in tactics, leading Finland's new government to avoid the Hanseatic and Frugal coalitionsmuch to the dismay of conservative and right-wing parties in the Finnish Parliament (Eduskunta, 2020). This ultimately changed three days into the July 2020 summit, when Finland's prime minister Sanna Marin joined the Frugals following heated exchanges with Southern European leaders (Khan, Fleming, \& Brunsden, 2020). For the most part, however, Finland avoided being associated with the Frugal Four, underscoring how domestic politics and different tactics among the Nordic countries can undermine the effectiveness of Nordic political cooperation in EU affairs.

\subsection{Official Nordic Cooperation on European Affairs}

Nordic attempts to influence EU policy through alliances such as the New Hanseatic League and the Frugal Four clearly follow the tradition of informal and intergovernmental political cooperation. While these initiatives are driven by national heads of government (Frugal Four) or finance ministers (New Hanseatic League), the official institutions of Norden seem to have little role to play on these debates. The limited role of the Nordic Council and the Nordic Council of Ministers may surprise against the backdrop of several declarations to increase their role for Nordic cooperation in EU affairs. However, these developments are in line with the limited impact of several initiatives to increase Norden's footprint in Brussels. One striking example includes the proposal to establish a joint office of the Nordic Council and the Nordic Council of Ministers in Brussels to represent Norden in the EU. The national governments in the Nordic Council of Ministers did not approve of the plan-presumably because of concerns about undermining their national representations (Opitz \& Etzold, 2018, p. 5). Even the inter-parliamentary Nordic Council was deeply split on the issue, as seen in an unusually contested 38-32 vote in favour of a much watered-down compromise to temporarily send a Nordic Council liaison officer to Brussels, which was opposed by the centre-right parties (NORDEN, 2016b).

This episode underlines that the Norden institutions' ambitions to strengthen their role in EU affairs after Brexit have thus far not substantially altered the state of play in Nordic political cooperation (Etzold \& Opitz, 2016). An external evaluation of the reform process 'The New North' (Nyt Norden) consequently finds that Norden has the "greatest room for improvement" regarding their stated goal of strengthening cooperation on international and EU issues (Resonans, 2018). As the existing institutional forms of Nordic cooperation did not allow much of joint Nordic positioning on EU affairs, Brexit as a potential critical juncture may have brought about far-ranging reforms to accommodate such ambitions. Yet no such developments can be observed, possibly owing to the 'moving-target' character of Brexit during the period under investigation. In this sense, Brexit resembles a complex 'known unknown' which makes it rational for other member states to adopt a 'wait and see' approach. Hence Brexit has thus far not altered the Nordics' preference for coordinating their positions informally through relatively loose and issuespecific intergovernmental coalitions rather than within the long-established official institutions of Norden. This preference for pragmatism might still change once Brexit becomes an established fact. Otherwise one will be tempted to agree with previous studies that the future of Nordic political cooperation may lie outside these institutions (Olesen \& Strang, 2016).

\section{Conclusion}

What emerges from our analysis is that Brexit introduces new dynamics into European politics by changing the coalitional logics among EU member states. The loss of a powerful ally pushes smaller and relatively prosperous states like the Nordics to voice their preferences more audibly, as experienced most clearly at the Special European Council summit of July 17-21, 2020. In lobbying against fiscal transfers and further integra- 
tion of core state powers, different alliances to maximise Nordic influence on EU politics have come into focus. Among these, the New Hanseatic League features as the broadest platform, attracting large numbers of member states in a flexible arrangement, where adherence and support varies depending on substantial policy issues. The Frugal Four, by contrast, follow a more transactional coalition logic, representing a relatively exclusive (and potentially volatile) club in which membership is based on the status of net-contributors and strong preferences for budgetary discipline. Both formats have assumed considerable prominence in post-Brexit EU politics and joining them has proven a surprisingly successful strategy for Nordic states to overcome their sizerelated disadvantages in EU decision-making, albeit to varying degrees. While the Nordics successfully opposed far-reaching EMU reforms in the context of the New Hanseatic League, they were forced to accept a decisive leap towards fiscal integration following the Covid-19 crisis. This suggests that, after Brexit, Nordic strategies to influence EU affairs may require both internal unity and (tacit) German approval to be effective.

While Brexit has pushed the Nordics to adopt a more prominent role in EU affairs, their preferred mode of cooperation remains informal and intergovernmental. This article identifies two important obstacles which keep the institutions of official Nordic cooperation from playing a more important role in EU affairs. First, the Nordic countries are "neither homogenous nor consistent with respect to EU integration" (Grøn \& Wivel, 2018, p. 269). This is particularly true concerning EMU, where Finland's status as the Nordic's only full EU-insider contrasts with the more hesitant approach of its neighbours, thus limiting their ability to cooperate across the board. Considering the particular obstacles the Nordic euro outsiders face to effectively influence EMU reform, their relative success in doing so suggests that Nordic coalition-building may be even more successful in less 'difficult' policy areas such as health policy or environmental protection. Second, the opposition to increasing the presence of Nordic cooperation in Brussels through a joint representation of the 'Norden' institutions signals that there are continued reservations regarding the strengthening of institutions above the national level, be they European or Nordic. In this sense, the Nordics are often not only reluctant Europeans but also 'reluctant Nordics' (Arter, 1999, p. 311). Both aspects are nothing new and have complicated Nordic political cooperation for decades. While one might have expected the external shock of Brexit to raise the costs of non-cooperation for Nordic countries sufficiently to break with this pattern, the empirical record thus far suggests otherwise.

\section{Acknowledgments}

The authors would like to thank Frans Af Malmborg and Johan Erik Anderson for excellent research assistance on the public and parliamentary debates on EU policy within
Sweden and Denmark, respectively. We are also grateful to Maria Kristiina Ranta for her translations of Finnish parliamentary debates, to three experts and (current and former) Nordic officials who shared their views in the context of informal background interviews, and to three anonymous reviewers for their insightful comments.

\section{Conflict of Interests}

The authors declare no conflict of interests.

\section{References}

A daunting task for the EU's economic liberals: The Hanseatic League will struggle to win support from Germany. (2018, April 11). Financial Times. Retrieved from https://www.ft.com/content/f30fadea-3d7911e8-b7e0-52972418fec4

Arregui, J., \& Thomson, R. (2009). States' bargaining success in the European Union. Journal of European Public Policy, 16(5), 655-676.

Arter, D. (1999). Scandinavian politics today: Manchester: Manchester University Press.

Arter, D. (2000). Small state influence within the EU: The case of Finland's 'Northern Dimension Initiative.' JCMS: Journal of Common Market Studies, 38(5), 677-697.

Bekker, S. (2018). Flexicurity in the European Semester: Still a relevant policy concept? Journal of European Public Policy, 25(2), 175-192.

Bengtsson, R., Elgström, O., \& Tallberg, J. (2004). Silencer or amplifier? The European Union presidency and the Nordic countries. Scandinavian Political Studies, 27(3), 311-334.

Björkdahl, A. (2008). Norm advocacy: A small state strategy to influence the EU. Journal of European Public Policy, 15(1), 135-154.

Brianson, A., \& Stegmann McCallion, M. (2020). Bang-aboomerang? Sweden, differentiated integration, and EMU after Brexit. In S. Gänzle, B. Leruth, \& J. Trondal (Eds.), Differentiated integration and disintegration in a post-Brexit era (pp. 146-163). London: Routledge.

Brunsden, J., \& Fleming, S. (2020, May 29). The quiet demise of the eurozone budget. Financial Times. Retrieved from https://www.ft.com/content/ dfcee508-51dc-4a10-9e77-17c40efe2458

Danish Ministry of Industry, Business and Financial Affairs. (2019). Task force concerning Denmark's possible participation in the Banking Union. Copenhagen: Danish Ministry of Industry, Business and Financial Affairs. Retrieved from https://eng.em.dk/ media/13398/eng_summary-002.pdf

Eduskunta. (2020). Parliamentary debate, 4 June 2020. Eduskunta. Retrieved from https://www. eduskunta.fi/Fl/vaski/PoytakirjaAsiakohta/Sivut/ PTK_87+2020+3.aspx\#19.16Kaunisto

Etzold, T., \& Opitz, C. (2016). Nordic Europe after the 
Brexit Vote: The five Nordic countries are reassessing their relations with the EU (SWP Comments 42). Berlin: German Institute for International and Security Affairs.

Finke, D. (2009). Challenges to intergovernmentalism: An empirical analysis of EU treaty negotiations since Maastricht. West European Politics, 32(3), 466-495.

Finnish Government. (2019). Speech by Minister for European Affairs Tytti Tuppurainen at Europe Forum Turku 30 August 2019. Finnish Government. Retrieved from https://valtioneuvosto.fi/en/ article/-/asset_publisher/10616/eurooppaministeritytti-tuppuraisen-puhe-turun-eurooppa-foorumissa30-8-2019

Frugal Four. (2020). Non-paper EU support for efficient and sustainable COVID-19 recovery. Amsterdam: Tweede Kamer der Staten-Generaal. Retrieved from https://www.tweedekamer.nl/downloads/document ?id=41d281d6-231c-4f7c-a3c3-040dac383f4c\&title =Non-paper\%20EU\%20support\%20for\%20efficient \%20and\%20sustainable\%20COVID-19\%20 recovery.pdf

Gänzle, S., \& Henökl, T. (2018). From 'awkward partner' to 'awkward partnership'? Explaining Norway's paradoxical relations with the European Union. In M. Stegmann McCallion \& A. Brianson (Eds.), Nordic states and European integration: Awkward partners in the North? (pp. 79-102). Cham: Springer International Publishing.

Golub, J. (2012). How the European Union does not work: National bargaining success in the Council of Ministers. Journal of European Public Policy, 19(9), 1294-1315.

Grøn, C. H., Nedergaard, P., \& Wivel, A. (2015). The Nordic countries and the European Union: Still the other European community? Abingdon: Routledge.

Grøn, C. H., \& Wivel, A. (2018). Scandinavia and the European Union: Pragmatic functionalism reconsidered. In P. Nedergaard \& A. Wivel (Eds.), The Routledge handbook of Scandinavian politics (pp. 269-280). London and New York, NY: Routledge.

Haas, J. S., D'Erman, V. J., Schulz, D. F., \& Verdun, A. (2020). Economic and fiscal policy coordination after the crisis: Is the European Semester promoting more or less state intervention? Journal of European Integration, 42(3), 327-344.

Hanseatic League. (2008a, March 6). Finance ministers from Denmark, Estonia, Finland, Ireland, Latvia, Lithuania, the Netherlands and Sweden underline their shared views and values in the discussion on the architecture of the EMU [Press release]. Retrieved from https://www.government.se/statements/ 2018/03/finance-ministers-from-denmark-estoniafinland-ireland-latvia-lithuania-the-netherlands-andsweden

Hanseatic League. (2008b, July 18). Shared views of the Finance Ministers from Denmark, Estonia, Finland, Ireland, Latvia, Lithuania, Sweden, and The Nether- lands about Capital Markets Union [Press release]. Retrieved from https://www.government.se/ statements/2018/07/shared-views-of-the-financeministers-from-denmark-estonia-finland-irelandlatvia-lithuania-sweden-and-the-netherlands-aboutcapital-markets-union

Hanseatic League. (2008c, November 5). Shared views of the Finance Ministers from the Czech Republic, Denmark, Estonia, Finland, Ireland, Latvia, Lithuania, the Netherlands, Sweden and Slovakia on the ESM reform [Press release]. Retrieved from https://www.government.se/statements/2018/11/ shared-views-of-the-finance-ministers-from-theczech-republic-denmark-estonia-finland-irelandlatvia-lithuania-the-netherlands-sweden-andslovakia-on-the-esm-reform

Heisenberg, D. (2005). The institution of 'consensus' in the European Union: Formal versus informal decision-making in the Council. European Journal of Political Research, 44(1), 65-90.

Howarth, D., \& Quaglia, L. (2018). The difficult construction of a European Deposit Insurance Scheme: A step too far in Banking Union? Journal of Economic Policy Reform, 21(3), 190-209.

Huhe, N., Naurin, D., \& Thomson, R. (2020). Don't cry for me Britannia: The resilience of the European Union to Brexit. European Union Politics, 21(1), 152-172.

Jakobsen, P. V. (2009). Small states, big influence: The overlooked Nordic influence on the civilian ESDP. JCMS: Journal of Common Market Studies, 47(1), 81-102.

Katzenstein, P. J. (1985). Small states in world markets: Industrial policy in Europe. Ithaca, NY: Cornell University Press.

Khan, M. (2018, November 27). New 'Hanseatic' states stick together in EU big league. Financial Times. Retrieved from https://www.ft.com/content/ f0ee3348-f187-11e8-9623-d7f9881e729f

Khan, M., \& Brunsden, J. (2020, July 9). Dutch resistance stands in way of deal on EU recovery fund. Financial Times. Retrieved from https://www.ft.com/content/ 13c622ad-9b1b-44ca-8054-206841c77a18

Khan, M., Fleming, S., \& Brunsden, J. (2020, July 22). Despite historic EU deal, deep rifts remain. Financial Times. Retrieved from https://www.ft.com/content/ Ofc2a2e6-791e-4f6f-bafc-e0c924aa398a

Korkman, S. (2015). EMU: Joining or not: Does it matter? In C. H. Grøn, P. Nedergaard, \& A. Wivel (Eds.), The Nordic countries and the European Union: Still the other European community? (pp. 173-187). Abingdon: Routledge.

Kurz, S. (2020, February 16). The 'frugal four' advocate a responsible EU budget. Financial Times. Retrieved from https://www.ft.com/content/7faae690-4e65 11ea-95a0-43d18ec715f5

Levy, J. S. (2002). Qualitative methods in international relations. In F. P. Harvey \& M. Brecher (Eds.), Evaluating methodology in international studies (pp. 
432-454). Ann Arbor, MI: University of Michigan Press.

Maes, I., \& Verdun, A. (2005). Small states and the creation of EMU: Belgium and the Netherlands, pacesetters and gate-keepers. Journal of Common Market Studies, 43(2), 327-348.

Miljan, T. (1977). The reluctant Europeans: The attitudes of the Nordic countries towards European integration. Montréal: McGill-Queen's University Press.

Naurin, D. (2007). Network capital and cooperation patterns in the working groups of the Council of the EU (EUI Working Paper RSCAS 2007/14). Florence: EUI.

NORDEN. (2016a). Nordens tid er nu: Nyt Norden 2.0-Næste fase af reformarbejdet [Norden's Time is Now: New Norden 2.0-The next stage of reform]. Copenhagen: NORDEN. Retrieved from http:// norden.diva-portal.org/smash/get/diva2:967562/ FULLTEXT02.pdf

NORDEN. (2016b). Nordic Council to open an office in Brussels. NORDEN. Retrieved from https:// www.norden.org/en/news/nordic-council-openoffice-brussels

Olesen, T. B., \& Strang, J. (2016). European challenge to Nordic institutional cooperation: Past, present and future. In J. Strang (Ed.), Nordic cooperation: A European region in transition (pp. 27-47). London and New York, NY: Routledge.

Opitz, C., \& Etzold, T. (2018). Seeking renewed relevance: Institutions of Nordic cooperation in the reform process (SWP Comments 3). Berlin: German Institute for International and Security Affairs.

Panke, D. (2010). Small states in the European Union: Structural disadvantages in EU policy-making and counter-strategies. Journal of European Public Policy, 17(6), 799-817.

Panke, D. (2011). Small states in EU negotiations: Political dwarfs or power-brokers? Cooperation and Conflict, 46(2), 123-143.

Panke, D., \& Gurol, J. (2019). Small states in the European Union. Oxford Research Encyclopedias. Retrieved from https://oxfordre.com/politics/oso/ viewentry/10.1093\$002facrefore\$002f97801902286 37.001.0001\$002facrefore-9780190228637-e-1485

Quaglia, L. (2010). Completing the single market in financial services: The politics of competing advocacy coalitions. Journal of European Public Policy, 17(7), 1007-1023.

Resonans. (2018). Evaluering af reformarbejdet $N y t$ Norden i Nordisk Ministerråd 2014-2017 [Evaluation of the reform process 'The New North' in the Nordic Council of Ministers 2014-2017]. Copenhagen: NORDEN. Retrieved from https://www.norden.org/ sites/default/files/2018-08/Evaluering\%20af\%20Nyt \%20Norden\%2026-04-18.pdf

Ruse, I. (2015). Nordic cooperation in the EU Council: Does institutional embeddedness matter? In C. H. Grøn, P. Nedergaard, \& A. Wivel (Eds.), The Nordic countries and the European Union: Still the other European community? (pp. 53-67): Abingdon: Routledge.

Sandbu, M. (2020, July 22). EU crosses the Rubicon with its emergency recovery fund. Financial Times. Retrieved from https://www.ft.com/content/ bd570dde-3095-4074-bd37-18003f2bd3c2

Schoeller, M. G. (2020). Preventing the eurozone budget: Issue replacement and small state influence in EMU. Journal of European Public Policy, 1-21. https://doi. org/10.1080/13501763.2020.1795226

Slapin, J. B. (2008). Bargaining power at Europe's intergovernmental conferences: Testing institutional and intergovernmental theories. International Organization, 62(1), 131-162.

Spendzharova, A. B., \& Bayram, I. E. (2016). Banking union through the back door? How European banking union affects Sweden and the Baltic States. West European Politics, 39(3), 565-584.

Stegmann McCallion, M., \& Brianson, A. (Eds.). (2018). Nordic states and European integration: Awkward partners in the north? Cham: Springer.

Swedish Ministry of Finance. (2019). Sweden and the banking union: Summary. Swedish Ministry of Finance. Retrieved from https://www.government. se/legal-documents/2019/12/sweden-and-thebanking-union---summary

Thorhallsson, B., \& Wivel, A. (2006). Small states in the European Union: What do we know and what would we like to know? Cambridge Review of International Affairs, 19(4), 651-668.

Verdun, A. (2020). The greatest of the small? The Netherlands, the New Hanseatic League and the Frugal Four. Manuscript submitted for publication.

Wivel, A. (2018). As awkward as they need to be: Denmark's pragmatic activist approach to Europe. In M. Stegmann McCallion \& A. Brianson (Eds.), Nordic states and European integration: Awkward partners in the north? (pp. 13-34). Cham: Springer International Publishing.

\section{About the Authors}

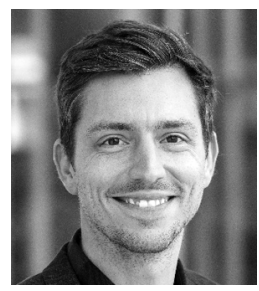

Daniel F. Schulz (PhD) is Postdoctoral Research Fellow in European Studies at the University of Agder. His research focuses on monetary policy, financial regulation, and the politics of taxation. He is particularly interested in European governments' different approaches to EMU and how the influence of voters and interest groups in European integration is mediated by ideas and institutions. Some of his past work has been published in the Journal of European Integration and JCMS: Journal of Common Market Studies. 
Thomas Henökl (PhD) works as Associate Professor of Public Policy at the University of Agder (Norway), and Senior Research Associate at the German Development Institute in Bonn. His interests lie in the fields of European politics, public administration, EU foreign and security policy, international cooperation and development, and more widely on comparative politics and organization theory. Previously, Thomas Henökl worked for the European Commission, DG Relex (from 2011 the European External Action Service), and at the European Institute of Public Administration (EIPA). 